\title{
An Investigation of the Relationship between the Anti-Inflammatory Activity, Polyphenolic Content, and Antioxidant Activities of Cooked and In Vitro Digested Culinary Herbs
}

\author{
Magali Chohan, Declan P. Naughton, Lucy Jones, and Elizabeth I. Opara \\ School of Life Sciences, Kingston University, Penrhyn Road, Kingston upon Thames KT1 2EE, UK \\ Correspondence should be addressed to Elizabeth I. Opara, e.opara@kingston.ac.uk
}

Received 10 February 2012; Accepted 14 March 2012

Academic Editor: David Vauzour

Copyright (C) 2012 Magali Chohan et al. This is an open access article distributed under the Creative Commons Attribution License, which permits unrestricted use, distribution, and reproduction in any medium, provided the original work is properly cited.

\begin{abstract}
There is little research on how cooking and digestion affect the anti-inflammatory activity of culinary herbs. Thus, the aim of this paper was to investigate this activity following cooking and in vitro digestion of the common culinary herbs, rosemary, sage, and thyme, and the relationship between their anti-inflammatory activity, polyphenol content, and antioxidant capacity. The antiinflammatory activity of uncooked (U), cooked (C), cooked and in vitro digested (C\&D), and standardised (STD, $30 \mathrm{mg} / \mathrm{mL}$ ) culinary herbs was assessed by measuring their effect on interleukin 8 (IL-8) release from stimulated human peripheral blood lymphocytes (PBLs) and Caco-2 cells. The trolox equivalent capacity (TEAC) and estimated total phenolic content of the herbs were also determined. There was a significant decrease in IL-8 release from PBLs stimulated with $\mathrm{H}_{2} \mathrm{O}_{2}$ incubated with (U), (C), (C\&D), and (STD) herbs and from Caco-2 cells stimulated with TNF $\alpha$ incubated with (C\&D) and (STD) herbs. PBLs preincubated with (C\&D) herbs prior to stimulation $\left(\mathrm{H}_{2} \mathrm{O}_{2}\right.$ or TNF $\left.\alpha\right)$ caused a significant inhibition in IL-8 release. The significant correlations between TEAC and estimated phenolic content and the anti-inflammatory activity suggest a possible contributory role of polyphenols to the anti-inflammatory activity of the culinary herbs investigated.
\end{abstract}

\section{Introduction}

There is growing evidence concerning the health-promoting potential of culinary herbs in a dietary context $[1,2]$, and the group of compounds that appear to be key contributors to this potential are the polyphenols. Polyphenols are major nonnutrient constituents of many common culinary herbs. Multiple studies, both epidemiological and experimental, suggest that polyphenols possess anti-inflammatory and antioxidant activity that may contribute, via the diet, to the prevention of chronic diseases such as cancer, cardiovascular disease, inflammatory bowel disease, and Alzheimer's [2-6]. Some polyphenols (caffeic acid, rosmarinic acid) known to be present in significant amounts in Labiatae culinary herbs, including rosemary, sage, and thyme [7], have been shown to affect the inflammatory response by inhibiting the action of proinflammatory cytokines such as IL-8 $[8,9]$. However, their mechanism of action has yet to be fully elucidated $[2,6]$. Culinary herbs are traditionally used in small amounts in the flavouring of food. Furthermore they are often cooked prior to consumption and, as with all foods, are affected by digestive processes following ingestion. Therefore, to gain a better understanding of the role that such herbs play in contributing to the dietary intake of polyphenols and their purported health-promoting properties, the impact of both cooking and digestion on the biological properties of these herbs needs to be established. Thus, the aims of this study were to determine the impact of cooking and in vitro digestion on the anti-inflammatory properties of the culinary herbs, rosemary, sage, and thyme and to determine whether this activity is associated with their polyphenol content and antioxidant capacity. 


\section{Material and Methods}

2.1. Reagents. Human salivary $\alpha$-amylase ( 100 units/mg; 1 unit corresponds to the amount of enzyme that liberates $1 \mu \mathrm{mol}$ of maltose per minute at $\mathrm{pH} 6.9$ at $25^{\circ} \mathrm{C}$ ), porcine pepsin (800-2.500 units/mg of protein; 1 unit gives a $\Delta \mathrm{A} 280$ of 0.001 per minute at $\mathrm{pH} 2$ at $37^{\circ} \mathrm{C}$ ), porcine pancreas pancreatin (4x U.S. Pharmacopeia), bile salts, hydrochloric acid $(\mathrm{HCl})$, sodium bicarbonate $\left(\mathrm{NaHCO}_{3}\right), 1,2$ ethyl acetate, formic acid, acetic acid, natural product reagent (NP), polyethylene glycol (PEG), 2,2-diphenyl-1-picrylhydrazyl (DPPH), ethanol, methanol, rosmarinic acid, sodium hydroxide $(\mathrm{NaOH}), 2,2^{\prime}$-azinobis (3-ethylbenzothiazoline6-sulfonic acid) diammonium salt (ABTS), Folin Ciocalteu reagent $(\mathrm{FC})$, sodium carbonate $\left(\mathrm{Na}_{2} \mathrm{CO}_{3}\right)$, gallic acid, 6-hydroxy-2,5,7,8-tetramethylchroman-2-carboxylic acid (97\%) (Trolox), phosphate buffered saline $5 \mathrm{mM}$ at $\mathrm{pH}$ 7.4 (PBS), potassium persulphate $\left(\mathrm{K}_{2} \mathrm{~S}_{2} \mathrm{O}_{8}\right)$, catalase (from bovine liver; 1 unit corresponds to the amount of enzyme which decomposes $1 \mu \mathrm{mol} \mathrm{H}_{2} \mathrm{O}_{2}$ per minute at $\mathrm{pH} 7.0$ and $\left.25^{\circ} \mathrm{C}\right)$, hydrogen peroxide $\left(\mathrm{H}_{2} \mathrm{O}_{2}\right)$, tumor necrosis factor alfa $(\mathrm{TNF} \alpha), 12$ and 48 well plates (Costar), Millex disposable syringe filter units, (pore size $0.22 \mu \mathrm{m}$, Millipore), and grade 1 filter paper (Whatman) were all purchased from Sigma Aldrich, Poole, UK. Dulbecco's modified Eagle's medium (DMEM) with glucose $(4.5 \mathrm{~g} / \mathrm{L}), 1 \%$ nonessential amino acids (NEAA), L-glutamine, RPMI 1640 medium, $100 \mathrm{U} / \mathrm{mL}$ penicillin $/ 100 \mu \mathrm{g} / \mathrm{mL}$ streptomycin and heat inactivated fetal bovine serum, 24 well plates (Coning), $15 \mathrm{~mL}$ and $25 \mathrm{~mL}$ flasks with vented caps (Coning), and Ficoll-Paque Plus were purchased from Fisher Scientific, Loughborough, Leicestershire, UK. Caco- 2 cells passage 44 were purchased from the European Collection of Cell Culture (ECACC), Health Protection Agency, Salisbury, UK. The Quantikine Elisa kit assay D8000C was purchased from R\&D systems, Oxon, UK.

2.2. Culinary Herbs. Rosemary (Rosmarinus officinalis), sage (Salvia officinalis), and thyme (Thymus vulgaris) dried and certified organic were purchased from Neal's Yard Remedies, Richmond, Surrey, UK and stored in air-tight containers in the dark at room temperature.

2.3. Preparation of Herb Samples. To mimic the cooking of these herbs as closely as possible, quantities of these herbs normally used in the preparation of food were used.

Uncooked herb samples (U) were prepared by adding herbs $(1 \mathrm{~g})$ to dark glass vials. These were then covered with water $\left(25 \mathrm{~mL}, 37^{\circ} \mathrm{C}\right)$ infused for 10 minutes, filtered (grade 1 filter paper), and then filter sterilised (pore size $0.22 \mu \mathrm{m}$ ). The mean amounts of plant material in these samples were estimated by allowing the water in these extracts to evaporate under a fan overnight until no moisture was visible and weighing the dry material (rosemary $(5.1 \pm 0.4 \mathrm{mg} / \mathrm{mL}$ ), sage $(6.5 \pm 0.7 \mathrm{mg} / \mathrm{mL})$, and thyme $(10.3 \pm 0.1 \mathrm{mg} / \mathrm{mL})$, $n=3)$.

Cooked herb samples (C) were prepared by heating herbs $(1 \mathrm{~g})$ in a Teflon stir frying pan for 10 minutes (without oil, as oils are known to possess antioxidant activity [10]); herbs were then prepared as described above.

Cooked and (in vitro) digested (C\&D) herb samples were prepared by heating the herbs $(1 \mathrm{~g})$ in a Teflon stir frying pan for 10 minutes (as described above). The herbs were then passed through a model of in vitro digestion with a simulated buccal fluid [11] and a simulated gastric and intestinal fluid $[12,13]$. Herbs $(C)(1 \mathrm{~g})$ were added to simulated buccal fluid $\left(14 \mathrm{~mL}, \mathrm{pH} 7.0,37^{\circ} \mathrm{C}\right.$ ) containing $\alpha$-amylase (1.4 units $/ \mathrm{mL}$ ) for 2 minutes in a preheated glass pestle and mortar. To simulate mastication, herbs were lightly crushed once. For the simulated gastric fluid, each buccal stage mixture was acidified to $\mathrm{pH} 2.0$ with $\mathrm{HCl}(5 \mathrm{~mL}, 0.1 \mathrm{~mol} / \mathrm{L})$. A solution $(1 \mathrm{~mL})$ of pepsin $(40 \mathrm{mg} / \mathrm{mL})$ in $\mathrm{HCl}(0.1 \mathrm{~mol} / \mathrm{L})$ was then added, and the mixture was then poured into a glass bottle, with a screw cap, and placed in a water bath (Grant, SS402. Fisher, UK) shaking at a rate of 190 strokes per minute so as to mimic the contractions of the human stomach. The mixtures were left in the simulated gastric fluid for 1 hour at $37^{\circ} \mathrm{C}$. For the simulated intestinal fluid, the $\mathrm{pH}$ of the mixture was raised to $\mathrm{pH} 5-5.5$ by adding $\mathrm{NaHCO}_{3}(1 \mathrm{M}$, drop wise). A solution, containing $\mathrm{NaHCO}_{3}(5 \mathrm{~mL}, 0.1 \mathrm{M})$, pancreatin $(2 \mathrm{mg} / \mathrm{mL})$, and bile salts $(12 \mathrm{mg} / \mathrm{mL})$, was added and the mixture incubated for 2 hours $\left(37^{\circ} \mathrm{C}\right)$ in a water bath shaking at a rate of 190 strokes per minute so as to simulate the human small intestine during digestion. Sodium hydroxide $(\mathrm{NaOH}, 1 \mathrm{M})$ was added drop by drop to maintain the $\mathrm{pH}$ at 7.5. Control digests were also prepared (no herbs), and all samples were filtered (grade 1 filter paper) and filter sterilised (pore size $0.22 \mu \mathrm{m}$ ).

The $\mathrm{pH}$ of $(\mathrm{U}),(\mathrm{C})$, and $(\mathrm{C} \& \mathrm{D})$ herb samples was adjusted to $6.0 \pm 0.2$ using $\mathrm{HCl}(0.1 \mathrm{M}$ ) (as $\mathrm{pH}$ via changes in charge can affect the solubility and chelating capacity of antioxidants [14]) and stored at $-80^{\circ} \mathrm{C}$.

Preliminary studies carried out using the trypan blue exclusion test showed that the control digest and (C\&D) herb samples affected the viability of Caco-2 cells, possibly due to the digestive enzymes from the in vitro digestion process. To insure that these enzymes would not interfere with either of the cell assays, digestive enzymes were deactivated for all $(C \& D)$ herb samples by placing the entire preparation of each $(C \& D)$ herb samples and control digests in a glass test tube and placing this tube in boiled water for 5 minutes.

To gain a better understanding of the impact of the food matrix on the digestion of polyphenols in these culinary herbs, the effect of digestion on rosmarinic acid was carried out. Rosmarinic acid was chosen as has been determined from the literature to be a major polyphenol in the herbs selected for this study $[7,15,16]$. Rosmarinic acid (10 mg in $1 \mathrm{~mL}$ solution of $100 \mu \mathrm{L}$ ethanol and $900 \mu \mathrm{L}$ distilled water) was digested using the same in vitro process described above; however, it was not heated in a Teflon stir frying pan for 10 minutes as this was not practical. It was then compared to nondigested rosmarinic acid $(10 \mathrm{mg} / \mathrm{mL})$ to which the amount of distilled water added was equivalent to the amount of digestive fluids used throughout the in vitro digestion process.

Preliminary studies showed that the amount of plant material present in the extracts of the herb samples prepared 
varied; therefore standardised amounts of plant material (STD) were prepared in order to assess the effect of the same amount of plant material for each herb investigated. This was achieved by adding herbs $(1 \mathrm{~g})$ to dark glass vials. The herbs were then covered with water $(25 \mathrm{~mL}$, boiled), infused for 10 minutes at room temperature, filtered (grade 1 filter paper), and filter sterilised (pore size $0.22 \mu \mathrm{m}$ ). The water in these extracts was left to evaporate under a fan overnight until no moisture was visible. The resulting dry material was weighed and resuspended with sterile distilled water at $30 \mathrm{mg}$ of herb material $/ \mathrm{mL}$. The $\mathrm{pH}$ was then adjusted to $\mathrm{pH} 6 \pm 0.2$ and the samples stored at $-80^{\circ} \mathrm{C}$.

\subsection{Determination of Antioxidant Capacity and Estimated} Phenolic Content of Herb Samples. The antioxidant capacity of herb samples (U), (C), (C\&D), and (STD) was determined using the ABTS radical scavenging capacity assay [17]. Herb samples $(10 \mu \mathrm{L})$ were added to ABTS*+ stock solution $(990 \mu \mathrm{L})$ (with an absorbance of $0.700 \pm 0.02 \mathrm{nM}$ ), and absorbance values were read, after 5 minutes at $730 \mathrm{~nm}$ at room temperature, on a Helios $\beta$ spectrophotometer, (Unicam, UK). Trolox standards, prepared in ethanol, were diluted using PBS $(0-20 \mu \mathrm{M})$ and assayed with the samples, and blanks, to determine the trolox equivalent capacity (TEAC). Gallic acid equivalents (GAEs) were determined for herb samples (U), (C), (C\&D), and (STD) using the Folin Ciocalteu (FC) reagent as described previously [18]. However, bearing in mind that this reagent is reactive towards nonphenolic compounds, including ascorbic acid, it has been argued that this assay gives no more than a good "ballpark" estimation of total phenolic content [19]. Thus the values from this assay are expressed as estimated total phenolic content. Diluted herb samples and blanks $(100 \mu \mathrm{L})$ and gallic acid standards $(0.5-0.05 \mathrm{mg} / \mathrm{mL})$ were added to 12 well plates (Costar); then FC reagent $(200 \mu \mathrm{L})$ was added, followed by the addition of distilled water $(2 \mathrm{~mL})$ and $\mathrm{Na}_{2} \mathrm{CO}_{3}(15 \%)(1 \mathrm{~mL})$. Solutions were incubated for 2 hours and measured at $25^{\circ} \mathrm{C}$ at $765 \mathrm{~nm}$ on a Cary 50 Microplate Reader (Varian Inc, UK).

2.5. Determination of Antioxidant Activity and Polyphenol Profile Using Thin-Layer Chromatography (TLC). Herb samples, $\mathrm{pH} 6.0(5 \mu \mathrm{L})$, were spotted on to silica TLC plates $(10 \mathrm{~cm} \times 10 \mathrm{~cm})$ and air-dried. The solvent system used was 1,2 ethyl acetate, formic acid, acetic acid, and water $(100: 11: 11: 26)$ [20]. TLC plates were then air dried and sprayed with 2,2-diphenyl-1-picrylhydrazyl (DPPH) $(0.2 \%$ in methanol) to highlight antioxidant activity or natural product reagent (NP) and polyethylene glycol (PEG) to determine the presence of polyphenols. Yellow areas, against a purple background, corresponded to antioxidant activity. Areas of blue corresponded to phenolic acids, and green/yellow areas corresponded to other polyphenolic compounds. Reference standards ( $5 \mu \mathrm{L}, 500 \mathrm{ppm}$ ) of rosmarinic acid were also run.

2.6. Cell Culture. Ethical approval was obtained from the Ethics Committee of the Faculty of Science, Kingston
University, UK. Subjects were recruited once they had read the participant information sheet and had given informed consent. Blood collections and storage procedures were carried out in accordance with the UK Human Tissue Act [21]. Peripheral blood lymphocytes (PBLs) were isolated from heparinised venous whole blood ( $15 \mathrm{~mL}$ ) using Ficoll-Paque Plus and then cultured in RPMI media supplemented with $10 \%$ heat inactivated fetal bovine serum (FBS) and $100 \mathrm{U} / \mathrm{mL}$ penicillin $/ 100 \mu \mathrm{g} / \mathrm{mL}$ streptomycin, placed in $15 \mathrm{~mL}$ flasks with vented caps (Coning) to incubate at $37^{\circ} \mathrm{C}$ and $5 \% \mathrm{CO}_{2}$ atmosphere for 24 hours and used promptly for cytotoxicity tests or ELISA assays. Caco-2 cell lines were established and maintained by serial passage in a standard sterile tissue culture environment [22]. Cells were cultured with Dulbecco's modified Eagle's medium (DMEM) $(500 \mathrm{~mL})$ containing glucose $(4.5 \mathrm{~g} / \mathrm{L}), 1 \%$ nonessential amino acids (NEAA), supplemented with $1 \%$ L-glutamine, and heat inactivated fetal bovine serum (10\%). Cells were placed in $25 \mathrm{~mL}$ culture flasks with vented caps (Coning), incubated at $37^{\circ} \mathrm{C}$ and $5 \% \mathrm{CO}_{2}$ and grown for 14 days prior to carrying out cytotoxicity tests or ELISA assays.

\subsection{Cytotoxicity Tests on PBLs and Caco-2 Cells Exposed to} Herb Samples. In order to ensure that herb samples were not toxic to the cell lines, cytotoxicity tests were performed. PBLs cells were seeded at a concentration of $1 \times 10^{5}$ cells $/ \mathrm{mL}$ in 48 well plates (coning) and incubated with herb samples (diluted 1:10 in fresh FBS-free RPMI media supplemented with $100 \mathrm{U} / \mathrm{mL}$ penicillin $/ 100 \mu \mathrm{g} / \mathrm{mL}$ streptomycin). Caco2 cells seeded at $2 \times 10^{5}$ in 24 well plates (Coning) were grown for 14 days; the media were replaced every 3-4 days. Cells were washed 3 times in PBS and then incubated with herb samples (diluted 1:10 in FBS-free DMEM with glucose $(4.5 \mathrm{~g} / \mathrm{L}), 1 \%$ nonessential amino acids (NEAA), supplemented with $1 \%$ L-glutamine). Both cell lines were placed in an incubator $\left(37^{\circ} \mathrm{C}\right)$ and $5 \% \mathrm{CO}_{2}$ for 24 hours with herb samples and controls and assessed for cytotoxicity using the trypan blue exclusion test.

2.8. Assay for Catalase-Like Activity. The potential catalaselike activity for each herb sample was investigated to rule out the potential inactivation of $\mathrm{H}_{2} \mathrm{O}_{2}$ by the samples through catalase-like activity. The assay was carried out using standard manometry; catalase was used as the positive control [23].

\subsection{Investigation of the Anti-Inflammatory Activity of Herb Samples on PBLs and Caco-2 Cells. The anti-inflammatory activities of the herb samples were assessed in two ways so as to provide insight into how the herb samples affected the action of the proinflammatory factors $\mathrm{H}_{2} \mathrm{O}_{2}$ and TNF- $\alpha$. First, PBLs and Caco-2 cells were coincubated with (U), (C), (C\&D), and standardised (STD) herb samples, diluted $1: 10$ in respective medium, and $\mathrm{H}_{2} \mathrm{O}_{2}(2 \mathrm{mM})$ or TNF $\alpha$ $(100 \mu \mathrm{g} / \mathrm{mL})$ for 24 hours. Cells were also preincubated for 3 hours with $(\mathrm{C} \& \mathrm{D})$ herb samples, diluted $1: 10$ in medium, to determine if the herbs following cooking and in vitro digestion were able to protect the cells from proinflammatory}






Figure 1: Antioxidant capacity (TEAC) and total phenolic content (GAE) of herb extracts. Data are presented as the mean $\pm \mathrm{SD}$ $(n=3)$. NS: no significant differences between TEAC rosemary $(\mathrm{U})$ and rosemary $(\mathrm{C})(P \geq 0.05)$ and no significant differences between GAE rosemary $(\mathrm{U})$ and rosemary $(\mathrm{C})(P \geq 0.05)$. ${ }^{\mathrm{a}} P \leq$ 0.001 (C\&D) herb samples significantly different from their (U) \& (C) counterparts. ${ }^{\mathrm{b}} P \leq 0.05(\mathrm{C})$ herb samples significantly different from their $(\mathrm{U})$ counterparts. STD: standardised herb sample $(30 \mathrm{mg} / \mathrm{mL})$.

factors. These cells were then exposed to $\mathrm{H}_{2} \mathrm{O}_{2}$ or TNF $\alpha 24$ hours at the concentrations stated above. PBL and Caco-2 controls were set up, in their respective media, with $\mathrm{H}_{2} \mathrm{O}_{2}$ or TNF $\alpha$ only at the concentrations stated above. Spontaneous release of IL- 8 was assessed by incubating cells in media only (in the absence of herb samples, $\mathrm{H}_{2} \mathrm{O}_{2}$ or TNF $\alpha$ ). Cells were also exposed to (U), (C), (C\&D) blank digest, and (STD) samples (diluted $1: 10$ in their respective media) to determine they if they affected IL- 8 release in the absence of $\mathrm{H}_{2} \mathrm{O}_{2}$ or $\mathrm{TNF} \alpha$.

Media were then collected and their IL-8 concentrations determined using the quantitative sandwich enzyme immunoassay ELISA for interleukin-8 kit (carried out as per manufacturer's instructions) to ascertain if its release was affected. Plate absorbance values were read at $450 \mathrm{~nm}$ with a correction at $540 \mathrm{~nm}$ using a Cary 50 Microplate Reader (Varian Inc, UK).

2.10. Expression of Data and Statistical Analysis. Data are expressed as means of triplicate analysis \pm SEM, $(n=3)$ unless otherwise stated. Statistical analyses were performed using SPSS for windows (Version 17). The antioxidant capacity was expressed in $\mu$ moles TEAC/g herb and estimation of total phenolic content in mg GAE/g herb. Mean values for blank digest samples were subtracted from respective TEAC and GAE values for C\&D herb samples. ANOVA with post hoc Tukey were used to compare TEAC and GAE of (U), (C), (C\&D), and STD herb samples. The independent sample $t$-test was used to compare the TEAC of rosmarinic acid digested to rosmarinic acid nondigested. The percentage inhibition of IL- 8 release from PBLs or Caco- 2 cells was determined using the following equation: ((IL-8 release from respective control cells (stimulated by $\mathrm{H}_{2} \mathrm{O}_{2}$ or TNF $\alpha$ )IL-8 release from cells coincubated or preincubated with herb samples and $\mathrm{H}_{2} \mathrm{O}_{2}$ or TNF $\alpha$ )/IL- 8 release from respective control cells (stimulated by $\mathrm{H}_{2} \mathrm{O}_{2}$ or $\mathrm{TNF} \alpha$ ) $) \times 100$. As percentages are bound data, the percentages for IL-8 inhibition were checked for normality using the ShapiroWilk test. ANOVA with post hoc Tukey was then used to compare the percentage inhibition by herb samples (U), (C), (C\&D), and (STD) preincubated with $\mathrm{H}_{2} \mathrm{O}_{2}$ or TNF $\alpha$ against their respective controls. Pearson's correlation coefficients $(r)$ with level of significance $(P \leq 0.05)$ (2-tailed) were used to compare all herb samples irrespective of treatments for TEAC and GAE assay results, and TEAC and GAE with percentage inhibition of TNF $\alpha$ or $\mathrm{H}_{2} \mathrm{O}_{2}$ stimulated IL-8 release by PBLs or Caco- 2 cells.

\section{Results}

3.1. Antioxidant Capacity and Estimated Total Phenolic Content of Herb Samples. The antioxidant capacity (TEAC) and estimated total phenolic content (GAE) of the (C\&D) herb samples were significantly higher than those of their (C) counterparts $(P \leq 0.001)$ which were significantly higher than those of the $(\mathrm{U})$ herb samples $(P \leq 0.05)$ with the exception of rosemary $(P \geq 0.05$ for both TEAC and GAE assays) (Figure 1). The TEAC and GAE for the (STD) herb samples were significantly higher than (U), (C), and (C\&D) samples $(P \leq 0.001)$ (Figure 1$)$. (STD) thyme was higher than (STD) sage and rosemary for both assays. For TEAC values for rosmarinic acid there was no statistical difference $(P=0.692)$ between nondigested rosmarinic acid $(2901 \pm 149.1 \mu$ moles TEAC/g) and digested rosmarinic acid $(2973.1 \pm 140.6 \mu$ moles TEAC/g $),(n=3)$.

3.2. Antioxidant Activity and Polyphenol Analysis Using TLC. For TLC plates sprayed with DPPH, all the (C\&D) herb samples provided a more intense yellow colour compared to their undigested $(\mathrm{U})$ and $(\mathrm{C})$ counterparts. This difference in colour indicated a higher antioxidant activity (Figure 2(a)). For the TLC plates sprayed with NP and PEG, phenolic acids appeared in shades of blue towards the top of the plates, and other polyphenolic compounds appeared in shades of green and yellow in the centre of the plates (Figure 2(b)). The colours of phenolic acids and other polyphenolic compounds were more intense for the (C\&D) herb samples, compared to their (U) and (C) counterparts, indicating higher levels of phenolic compounds. For (C) herbs, there was no difference in colour intensity for rosemary, a marginal increase in colour intensity for sage and an evident increase in colour intensity for thyme when compared with their (U) counterparts (Figures 2(a) and 2(b)).

3.3. Herb Samples Cell Cytotoxicity Tests and Catalase-Like Activity. The viability of both PBLs and Caco- 2 cells exposed to $(\mathrm{U}),(\mathrm{C})(\mathrm{C} \& \mathrm{D})$, and (STD) herb samples diluted 1 in $10 \mathrm{in}$ respective media for 24 hours was not significantly different from that of the controls $(P>0.05$, data not shown). 


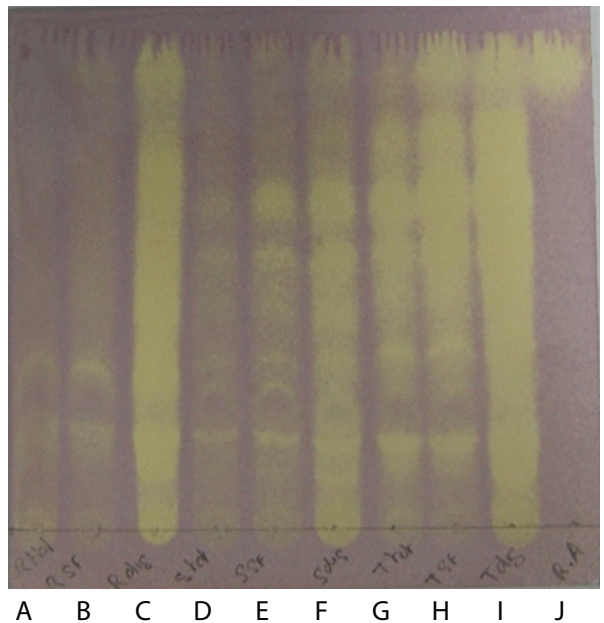

(a)

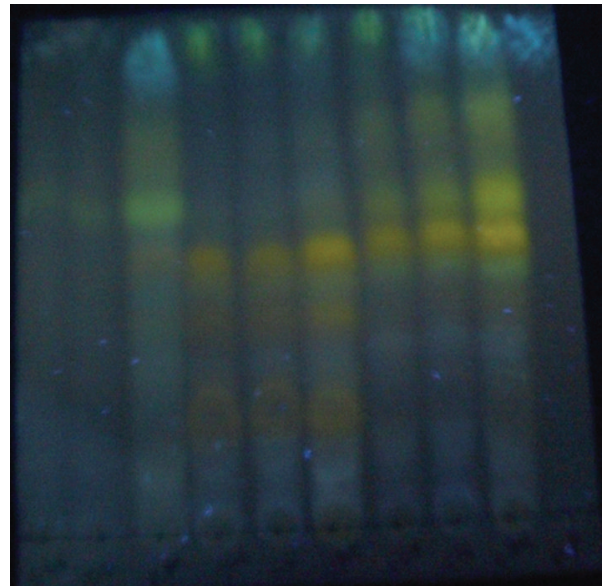

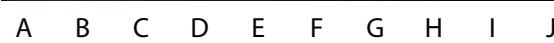

(b)

Figure 2: Percentage inhibition of IL-8 release by $\mathrm{H}_{2} \mathrm{O}_{2}$ or TNF $\alpha$ exposed PBLs pre-incubated or co-incubated with herb samples. (a) TLC plate spotted with herb samples $(5 \mu \mathrm{L}, \mathrm{pH} 6)$ and rosmarinic acid $(0.5 \mathrm{mg} / \mathrm{mL})$ and sprayed with $2 \%$ DPPH. The yellow areas correspond to antioxidant activity. A: rosemary (U), B: rosemary (C), C: rosemary (C\&D), D: sage (U), E: sage (C), F: sage (C\&D) G: thyme (U), H: thyme $(\mathrm{C})$, I: thyme (C\&D), J: rosmarinic acid (U) uncooked, (C) heated, (C\&D) heated, and digested. (b) TLC plate spotted with herb samples $(5 \mu \mathrm{L}, \mathrm{pH} 6)$ and rosmarinic acid $(0.5 \mathrm{mg} / \mathrm{mL})$ and sprayed with natural product reagent $(\mathrm{NP})$ and polyethylene glycol (PEG). Phenolic acids appear in shades of blue towards the upper part of the plate and other polyphenolic compounds appear in a range of shades of green and yellow in the centre of the plate. A: rosemary $(\mathrm{U})$, B: rosemary $(\mathrm{C}), \mathrm{C}$ : rosemary $(\mathrm{C} \& \mathrm{D}), \mathrm{D}$ : sage $(\mathrm{U}), \mathrm{E}$ : sage $(\mathrm{C}), \mathrm{F}$ : sage $(\mathrm{C} \& \mathrm{D}) \mathrm{G}$ : thyme $(\mathrm{U}), \mathrm{H}$ : thyme $(\mathrm{C})$, I: thyme (C\&D), J: rosmarinic acid (U) uncooked, (C) heated, (C\&D) heated and digested.

None of the herb samples exhibited catalase-like activity indicating that $\mathrm{H}_{2} \mathrm{O}_{2}$ was not inactivated by these samples.

\subsection{Spontaneous Release of IL-8 from PBLs and Caco-2 Cells Compared to TNF $\alpha$ and $\mathrm{H}_{2} \mathrm{O}_{2}$ Stimulated PBL and Caco- 2 Cell Controls. Spontaneous IL-8 release was detected for both PBLs $(855.5 \pm 10.7 \mathrm{pg} / \mathrm{mL}, n=8)$ and Caco- 2 cells $(60.4 \pm 1.1 \mathrm{pg} / \mathrm{mL}, n=6)$. Exposure of cells to TNF $\alpha$ sig- nificantly increased IL-8 release compared to nonstimulated cells $(P \leq 0.05)$ for both PBL $(1011 \pm 63.9 \mathrm{pg} / \mathrm{mL}, n=6)$ and Caco-2 Cells $(183 \pm 14.5 \mathrm{pg} / \mathrm{mL}, n=6)$. Exposure of cells to $\mathrm{H}_{2} \mathrm{O}_{2}$ significantly increased IL- 8 release compared to nonstimulated cells $(P \leq 0.05)$ for both PBLs $(1144.6 \pm$ $47.5 \mathrm{pg} / \mathrm{mL}, n=6)$ and Caco-2 Cells $(91.8 \pm 8.2 \mathrm{pg} / \mathrm{mL}$, $n=6)$. None of the herb samples had a significant effect on spontaneous IL-8 release from either cell lines.}

3.5. Effect of Coincubation of Herb Samples with $\mathrm{H}_{2} \mathrm{O}_{2}$ or $T N F \alpha$. For $(\mathrm{U}),(\mathrm{C})$, and $(\mathrm{C} \& \mathrm{D})$ herb samples there were decreases in IL- 8 release from PBLs but these decreases were only significant for PBLs, stimulated by $\mathrm{H}_{2} \mathrm{O}_{2}(P \leq 0.05$, Figure 3 ) with the exception of $(\mathrm{C})$ rosemary. (C\&D) herb samples significantly decreased the release of IL- 8 from Caco2 cells stimulated by $\mathrm{TNF} \alpha(P \leq 0.001$, Figure 4$)$. (STD) herb samples significantly inhibited the release of IL- 8 from PBLs stimulated by $\mathrm{H}_{2} \mathrm{O}_{2}$ and PBLs stimulated by TNF $\alpha$ $(P \leq 0.001$, Figure 3$)$. (STD) herb samples significantly decreased the release of IL- 8 from Caco- 2 cells stimulated by $\mathrm{TNF} \alpha(P \leq 0.001$, Figure 4$)$. (U), (C), (C\&D), and (STD)

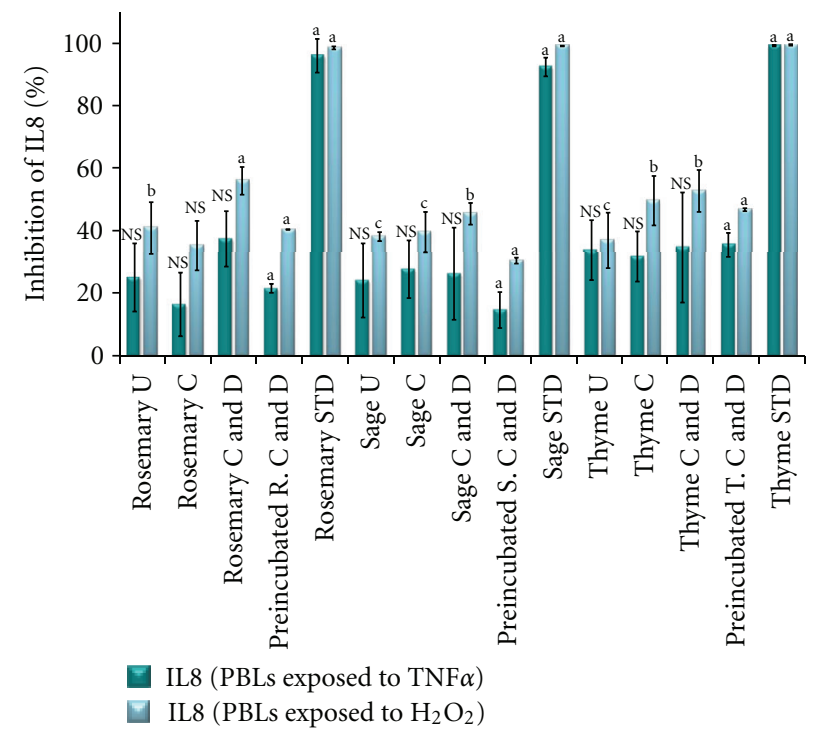

FIgure 3: Percentage inhibition of IL- 8 release by TNF $\alpha$ exposed Caco-2 cells pre-incubated or co-incubated with herb samples. (R.): Rosemary, (S.): Sage, (T.): Thyme. Data are presented as the means \pm SEM $(n=3)$. \%inhibition of IL- $8=[($ IL- 8 release from control PBLs (stimulated by $\mathrm{H}_{2} \mathrm{O}_{2}$ or TNF $\alpha$ )-IL- 8 release from PBLS co-incubated/pre-incubated with herb samples)/IL-8 release from control PBLs (stimulated by $\mathrm{H}_{2} \mathrm{O}_{2}$ or TNF $\alpha$ )-] $\times 100$. Significant differences between IL-8 released from control PBLs and PBLs co-incubated/pre-incubated with herb samples, ${ }^{a} P \leq 0.001$, ${ }^{\mathrm{b}} P \leq 0.01,{ }^{\mathrm{c}} P \leq 0.05, n=3$. NS: nonsignificant difference between IL-8 release for control PBLs and that of PBLs co-incubated with herb samples and TNF $\alpha$ or $\mathrm{H}_{2} \mathrm{O}_{2}$, or pre-incubated with herb samples. 


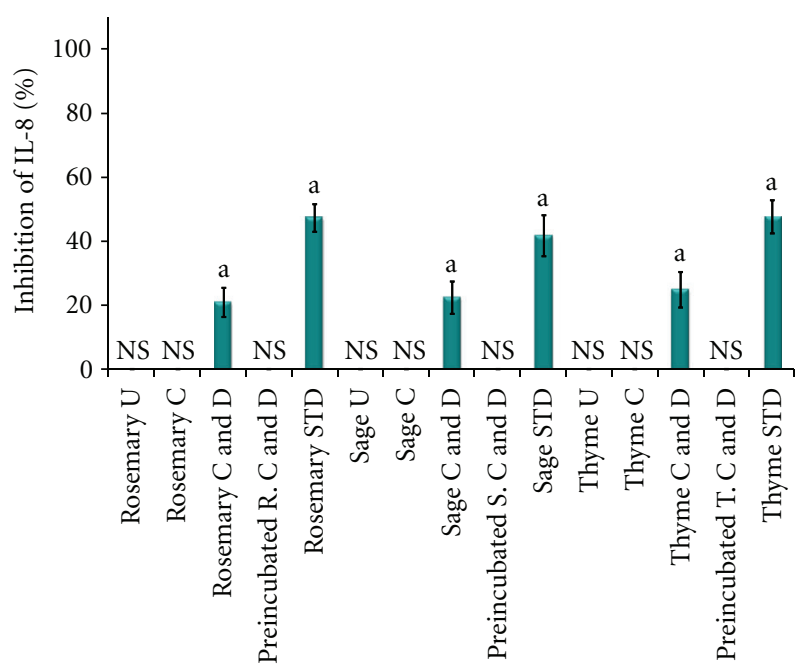

Figure 4: Percentage inhibition of IL- 8 release by TNF $\alpha$ exposed Caco-2 cells pre-incubated or co-incubated with herb samples. (R.): Rosemary, (S.): Sage, (T.): Thyme. Data are presented as the Means \pm SEM $(n=3)$. \%inhibition of IL- $8=[($ IL- 8 release from control Caco- 2 cells (stimulated by TNF $\alpha$ )-IL- 8 release from Caco2 co-incubated/pre-incubated with herb samples)/IL-8 release from control Caco-2 cells (stimulated by TNF $\alpha$ )] $\times 100]$. Significant differences between IL-8 released from control PBLs and PBLs coincubated/pre-incubated with herb samples, ${ }^{\mathrm{a}} P \leq 0.001,(n=3)$. NS: nonsignificant difference between IL-8 release for Caco- 2 cells control $(\mathrm{TNF} \alpha)$ and that of Caco-2 cells co-incubated with herb samples and TNF $\alpha$, or pre-incubated with herb samples.

herb samples had no effect on IL-8 release from Caco-2 cells stimulated by $\mathrm{H}_{2} \mathrm{O}_{2}$ (data not shown).

3.6. Effect of Preincubation with Herb Samples prior to Adding $\mathrm{H}_{2} \mathrm{O}_{2}$ or $T N F \alpha$. Preincubation with (C\&D) herb samples caused a significant decrease in IL-8 release from PBLs stimulated by $\mathrm{H}_{2} \mathrm{O}_{2}$ or TNF $\alpha(P \leq 0.001$, Figure 3$)$. Preincubating the Caco-2 cells with (C\&D) herb samples had no effect on IL- 8 release when stimulated by $\mathrm{H}_{2} \mathrm{O}_{2}$ or TNF $\alpha$ (Figure 4).

3.7. Correlations between Antioxidant Capacities, Total Phenolic Contents, and Anti-Inflammatory Activities of Culinary Herbs, Irrespective of Treatments. There was a strong correlation between TEAC and GAE $(r=0.989, P \leq 0.01)$, (Table 1$)$ and between the \%decrease in IL- 8 release caused by herb samples for $\mathrm{H}_{2} \mathrm{O}_{2}$ or TNF- $\alpha$ stimulated PBLs and their estimated total phenolic content and antioxidant capacity $(P \leq 0.01$, Table 1$)$. There was a strong and significant correlation between the \%decrease in IL- 8 release from TNF$\alpha$ stimulated Caco- 2 cells and their estimated total phenolic content and antioxidant capacity $(r=0.892, P \leq 0.01$, Table 1).

\section{Discussion}

The aims of this study were, first, to investigate what effect cooking and digestion in vitro have on the anti-inflammatory activity of the culinary herbs rosemary, sage, and thyme and, second, to investigate if there is an association between the anti-inflammatory activity and the antioxidant capacity and estimated total phenolic content of these herbs.

Based on the co- and preincubation experiments, this study indicates that rosemary, sage and thyme (U), (C), (C\&D) and (STD) significantly decrease IL-8 release via inhibition of, and protection against, the action of $\mathrm{H}_{2} \mathrm{O}_{2}$ or TNF $\alpha$. The anti-inflammatory action of the herbs was far greater for the PBLs than for the Caco-2 cells. In fact, with the exception of (C\&D) and (STD) herbs in TNF $\alpha$ stimulated Caco-2 cells, none of the other herb samples showed any anti-inflammatory action based on the inhibition of IL-8 release for both $\mathrm{H}_{2} \mathrm{O}_{2}$ or TNF $\alpha$ stimulated Caco- 2 cells. The Caco- 2 cell line is a transformed human colonic adenocarcinoma; however, the PBLs are mature "healthy" lymphocytes, and these differences might explain the difference observed in IL-8 release [24].

Cooking the herbs did not consistently significantly increase their estimated total phenolic content or antioxidant capacity, compared to (U) herbs in the current study. Other studies that have looked at the impact of cooking on various plant foods concur that differences in polyphenol activity content are due to both the food matrix and the cooking techniques employed [25-27]. Cooking followed by in vitro digestion did elicit significant increases in TEAC and GAE compared to (U) and (C) herbs in the current study. In relation to the literature the impact of digestion on polyphenols using in vitro models resulted in decreases in activity in fruits juices [28] and either no changes or decreases in herbal teas (infusions from powdered herbs) [29]. These differences may be due to the nature of the food matrix (whole herbs were used in the current study) as well as the type of in vitro model of digestion used.

Analysis using TLC showed the presence of phenolic acids and other polyphenolic compounds in the (U) herb samples which agrees well with the literature $[16,20,30]$. However, to the authors' knowledge, no TLC work has been done to determine the polyphenolic profiles of rosemary, sage, and thyme following cooking and digestion in vitro. TLC results from the present study did not suggest that new compounds were formed or lost as a result of cooking as the profiles for (C) versus (U) herb samples were identical for rosemary and more intense in colour for sage and thyme but not dissimilar. The in vitro digestion process increased the levels of phenolic acids and other polyphenolic compounds. These observations are supported by the increases in the antioxidant capacity, activity (TLC), and estimated total phenolic content data. Rosmarinic acid, measured via the TEAC assay, was not affected by in vitro digestion, and although the effect of cooking on rosmarinic acid was not investigated, the lack of difference in TEAC and GAE in (C) compared to (U) herbs strongly indicates that polyphenols in these herbs, including rosmarinic which is a predominant polyphenol in these herbs, were not decreased as a consequence of the cooking method used.

A positive linear correlation has been established between polyphenols and antioxidant capacity of herbs [16]. Polyphenols are thought to be most concentrated in the vacuoles of 
TABLe 1: Correlations between antioxidant capacities, estimated total phenolic content, and \%decrease in IL-8 release irrespective of treatments.

\begin{tabular}{lcr}
\hline Correlations & $r$ & $P$ \\
\hline GAE versus TEAC & 0.989 & $\leq 0.01$ \\
\%decrease in IL-8 for PBLs exposed to TNF $\alpha$ versus GAE & 0.914 & $\leq 0.01$ \\
\%decrease in IL-8 for PBLs exposed to TNF $\alpha$ versus TEAC & 0.901 & $\leq 0.01$ \\
\%decrease in IL-8 for PBLs exposed to $\mathrm{H}_{2} \mathrm{O}_{2}$ versus GAE & 0.922 & $\leq 0.01$ \\
\%decrease in IL-8 for PBLs exposed to $\mathrm{H}_{2} \mathrm{O}_{2}$ versus TEAC & 0.905 & $\leq 0.01$ \\
\%decrease in IL-8 release for Caco-2 exposed to TNF $\alpha$ versus GAE & 0.876 & $\leq 0.01$ \\
\%decrease in IL-8 release Caco-2 exposed to TNF $\alpha$ versus TEAC & 0.892 & $\leq 0.01$ \\
\hline
\end{tabular}

paraveinal and parenchymal cells below the epidermis [31]. Thus, the increase in antioxidant capacity and estimated phenolic content is likely to be due to the breakdown of the herbs' plant cell walls via the in vitro digestion process, facilitating the release of polyphenols. The antioxidant capacity, estimated total phenolic content, and anti-inflammatory effects of (STD) herb samples were by far the greatest (thyme >sage, rosemary). This is most likely to be due to a greater concentration of plant material $(7.3 \pm 2.4 \mathrm{mg} / \mathrm{mL}$ for (U) and $30 \mathrm{mg} / \mathrm{mL}$ for (STD) herb samples) and thus a greater concentration of polyphenols resulting in a dosedependant response. This is further supported by the much greater decrease in IL-8 release that resulted when stimulated cells, (with the exception of $\mathrm{H}_{2} \mathrm{O}_{2}$ stimulated Caco-2 cells), were coincubated with (STD) herb samples, thus corroborating the role of polyphenols as significant contributors to the anti-inflammatory properties of these herbs.

The mechanism of action to explain the effect of the herbs on IL-8 release is unclear. However, evidence suggests that polyphenols may play a role in the anti-inflammatory activity reported in the current study. Rosmarinic acid is the predominant polyphenol in rosemary, sage, and thyme $[7,15,16,30,32]$. The effectiveness of rosmarinic acid in reducing inflammation by inhibiting the proinflammatory PKC/NF- $\kappa \mathrm{B}$ pathway was demonstrated in mice [33]. Therefore it is possible to speculate that the rosmarinic acid present in the herbs studied may be responsible, at least in part, for the IL-8 inhibition observed. In addition, caffeic acid, another polyphenol shown to be present in the herbs investigated [7], was shown to inhibit both $\mathrm{H}_{2} \mathrm{O}_{2}$ and TNF $\alpha$ stimulated IL-8 release from Caco-2 cells [9]. This study indicated that inhibition occurred at the transcriptional and post-transcriptional level.

One clear difference observed in this study was that the inhibition of IL-8 release from PBLs stimulated by $\mathrm{H}_{2} \mathrm{O}_{2}$ was generally greater (and more statistically significant) than for those stimulated by TNF $\alpha$. This difference may be because $\mathrm{TNF} \alpha$ and $\mathrm{H}_{2} \mathrm{O}_{2}$ may affect different inflammatory pathways within the cells or may affect the same inflammatory pathways differently [24].

It remains unclear why none of the herb samples inhibited IL-8 release from Caco-2 cells exposed to $\mathrm{H}_{2} \mathrm{O}_{2}$. Differences in $\mathrm{H}_{2} \mathrm{O}_{2}$ and $\mathrm{TNF} \alpha$ induced release of IL8 were also reported [9] with caffeic acid, a metabolite of rosmarinic acid. The authors demonstrated that caffeic acid $(2.00 \mathrm{mmol} / \mathrm{L})$ was able to inhibit the $\mathrm{H}_{2} \mathrm{O}_{2}$ or TNF $\alpha$ induced release of IL-8 from Caco-2 cells; however, whilst it was shown that caffeic acid inhibition appeared to occur via the inhibition of their expression of IL- 8 mRNA, it did not suppress the TNF $\alpha$-induced increase in the IL- 8 mRNA expression. That study suggests that the mechanisms by which polyphenols suppress the stimulation of IL-8 production and its subsequent release may differ based on the inflammatory stimulant. However, these results are in disagreement with the current study where only $\mathrm{TNF} \alpha$ stimulated IL-8 release was inhibited by the herb samples. As stated above, caffeic acid is a polyphenol found in all three culinary herbs investigated [7], although one must bear in mind that the concentration of polyphenols is affected by numerous factors including seasonal variations $[34,35]$ and the place of provenance $[15,36]$, as well as presale processing and storage [37] and also cooking $[25,26,38]$.

The strong and significant correlations between percentage inhibition of IL-8 release from the stimulated PBLs with TEAC and GAE, irrespective of treatments, suggest that there is an association between the antioxidant capacity, polyphenol content, and the anti-inflammatory activity of the herbs investigated $[5,9,39,40]$. In conjunction with literature concerning the anti-inflammatory activity of individual polyphenols, this association does provide compelling evidence that the polyphenols in these culinary herbs are major contributors to the inhibitory effects on IL-8 release reported. However, it is not clear if this action is in any way due to their antioxidant activity. Analytical methods would need to be employed to confirm this hypothesis and to clarify which polyphenols, including their metabolites, are responsible for the biological activities observed.

Whilst (STD) herb samples may not have a physiological relevance in terms of dietary intake, their use removed the impact that the amount of plant material has on antioxidant capacity, estimated total phenolic content, and anti-inflammatory activity when comparing the herbs. In addition, it also helped to demonstrate a dose-dependent relationship between the amount of herb and the antiinflammatory activity. The dose-response relationship is of particular interest since the amount of herbs used in the preparation of food varies [41] and also varies between individuals. A recent study showed that the consumption of herbs and spices ranged from 0.0 to $10.0 \mathrm{~g} /$ person/day [42]. 


\section{Conclusion}

In conclusion, that study shows that the culinary herbs rosemary, sage, and thyme, in quantities used for cooking, possess significant anti-inflammatory activity that may be due to their polyphenol content. Further work is required to fully elucidate the polyphenols responsible for this action and their mechanisms of action.

\section{Acknowledgments}

This paper was supported by Tamsyn Thring for the catalase assay. M. Chohan was the recipient of a Biomedical and Pharmaceutical Sciences Research Group, Kingston University, funded Ph.D.

\section{References}

[1] L. C. Tapsell, I. Hemphill, L. Cobiac et al., "Health benefits of herbs and spices: the past, the present, the future," The Medical Journal of Australia, vol. 185, no. 4, pp. S4-24, 2006.

[2] M. Viuda-Martos, Y. Ruiz-Navajas, J. Fernández-López, and J. A. Pérez-Álvarez, "Spices as functional foods," Critical Reviews in Food Science and Nutrition, vol. 51, no. 1, pp. 13-28, 2011.

[3] P. M. Kris-Etherton, K. D. Hecker, A. Bonanome et al., "Bioactive compounds in foods: their role in the prevention of cardiovascular disease and cancer," American Journal of Medicine, vol. 113, no. 9, pp. 71s-88s, 2002.

[4] M. Singh, M. Arseneault, T. Sanderson, V. Murthy, and C. Ramassamy, "Challenges for research on polyphenols from foods in Alzheimer's disease: bioavailability, metabolism, and cellular and molecular mechanisms," Journal of Agricultural and Food Chemistry, vol. 56, no. 13, pp. 4855-4873, 2008.

[5] C. M. Kaefer and J. A. Milner, "The role of herbs and spices in cancer prevention," Journal of Nutritional Biochemistry, vol. 19, no. 6, pp. 347-361, 2008.

[6] M. H. Pan, C. S. Lai, and C. T. Ho, "Anti-inflammatory activity of natural dietary flavonoids," Food and Function, vol. 1, no. 1, pp. 15-31, 2010.

[7] V. Neveu, J. Perez-Jiménez, F. Vos et al., "Phenol-Explorer: an online comprehensive database on polyphenol contents in foods," Database, vol. 2010, 2010.

[8] S. S. Huang and R. L. Zheng, "Rosmarinic acid inhibits angiogenesis and its mechanism of action in vitro," Cancer Letters, vol. 239, no. 2, pp. 271-280, 2006.

[9] Z. Zhao, S. S. Hee, H. Satsu, M. Totsuka, and M. Shimizu, "5-Caffeoylquinic acid and caffeic acid down-regulate the oxidative stress- and TNF- $\alpha$-induced secretion of interleukin- 8 from Caco-2 cells," Journal of Agricultural and Food Chemistry, vol. 56, no. 10, pp. 3863-3868, 2008.

[10] N. Pellegrini, M. Serafini, B. Colombi et al., "Total antioxidant capacity of plant foods, beverages and oils consumed in Italy assessed by three different in vitro assays," Journal of Nutrition, vol. 133, no. 9, pp. 2812-2819, 2003.

[11] I. Asano, K. Hamaguchi, S. Fujii, and H. Iino, "In vitro digestibility and fermentation of mannooligosaccharides from coffee mannan," Food Science and Technology Research, vol. 9, no. 1, pp. 62-66, 2003.

[12] R. P. Glahn, E. M. Wien, D. R. Van Campen, and D. D. Miller, "Caco-2 cell iron uptake from meat and casein digests parallels in vivo studies: use of a novel in vitro method for rapid estimation of iron bioavailability," Journal of Nutrition, vol. 126, no. 1, pp. 332-339, 1996.

[13] D. A. Garrett, M. L. Failla, and R. J. Sarama, "Development of an in vitro digestion method to assess carotenoid bioavailability from meals," Journal of Agricultural and Food Chemistry, vol. 47, no. 10, pp. 4301-4309, 1999.

[14] E. A. Decker, K. Warner, M. P. Richards, and F. Shahidi, "Measuring antioxidant effectiveness in food," Journal of Agricultural and Food Chemistry, vol. 53, no. 10, pp. 43034310, 2005.

[15] M. E. Cuvelier, H. Richard, and C. Berset, "Antioxidative activity and phenolic composition of pilot-plant and commercial extracts of sage and rosemary," Journal of the American Oil Chemists' Society, vol. 73, no. 5, pp. 645-652, 1996.

[16] B. Shan, Y. Z. Cai, M. Sun, and H. Corke, "Antioxidant capacity of 26 spice extracts and characterization of their phenolic constituents," Journal of Agricultural and Food Chemistry, vol. 53, no. 20, pp. 7749-7759, 2005.

[17] R. Re, N. Pellegrini, A. Proteggente, A. Pannala, M. Yang, and C. Rice-Evans, "Antioxidant activity applying an improved ABTS radical cation decolorization assay," Free Radical Biology and Medicine, vol. 26, no. 9-10, pp. 1231-1237, 1999.

[18] V. L. Singleton, Analytical Fractionation of the Phenolic Substances, 1974.

[19] J. D. Everette, Q. M. Bryant, A. M. Green, Y. A. Abbey, G. W. Wangila, and R. B. Walker, "Thorough study of reactivity of various compound classes toward the folin-Ciocalteu reagent," Journal of Agricultural and Food Chemistry, vol. 58, no. 14, pp. 8139-8144, 2010.

[20] H. Wagner and S. Bladt, Plant Drug Analysis: A Thin Layer Chromatography Atlas, Springer, London, UK, 2nd edition, 1996.

[21] Human Tissue Act, http://www.hta.gov.uk/.

[22] I. Behrens and T. Kissel, "Do cell culture conditions influence the carrier-mediated transport of peptides in Caco-2 cell monolayers?" European Journal of Pharmaceutical Sciences, vol. 19, no. 5, pp. 433-442, 2003.

[23] A. E. O. Fisher, S. C. Maxwell, and D. P. Naughton, "Catalase and superoxide dismutase mimics for the treatment of inflammatory diseases," Inorganic Chemistry Communications, vol. 6, no. 9, pp. 1205-1208, 2003.

[24] V. Lakshminarayanan, E. A. Drab-Weiss, and K. A. Roebuck, " $\mathrm{H}_{2} \mathrm{O}_{2}$ and tumor necrosis factor- $\alpha$ induce differential binding of the redox-responsive transcription factors AP- 1 and NF$\kappa \mathrm{B}$ to the interleukin- 8 promoter in endothelial and epithelial cells," Journal of Biological Chemistry, vol. 273, no. 49, pp. 32670-32678, 1998.

[25] C. Miglio, E. Chiavaro, A. Visconti, V. Fogliano, and N. Pellegrini, "Effects of different cooking methods on nutritional and physicochemical characteristics of selected vegetables," Journal of Agricultural and Food Chemistry, vol. 56, no. 1, pp. 139-147, 2008.

[26] N. Mulinacci, F. Ieri, C. Giaccherini et al., "Effects of cooking on the anthocyanins, Phenolic acids, glycoalkaloids, and resistant startch Content in two pigmented cultivars of Solanum tuberrosum L.", Journal of Agricultural and Food Chemistry, vol. 56, no. 24, pp. 11830-11837, 2009.

[27] N. Pellegrini, E. Chiavaro, C. Gardana et al., "Effect of different cooking methods on color, phytochemical concentration, and antioxidant capacity of raw and frozen brassica vegetables," Journal of Agricultural and Food Chemistry, vol. 58, no. 7, pp. 4310-4321, 2010.

[28] A. Cilla, A. González-Sarrías, F. A. Tomás-Barberán, J. C. Espín, and R. Barberá, "Availability of polyphenols in fruit 
beverages subjected to in vitro gastrointestinal digestion and their effects on proliferation, cell-cycle and apoptosis in human colon cancer Caco-2 cells," Food Chemistry, vol. 114, no. 3, pp. 813-820, 2009.

[29] M. S. Gião, S. Gomes, A. R. Madureira et al., "Effect of in vitro digestion upon the antioxidant capacity of aqueous extracts of Agrimonia eupatoria, Rubus idaeus, Salvia sp. and Satureja Montana," Food Chemistry, vol. 131, no. 3, pp. 761-767, 2011.

[30] H. Wang, G. J. Provan, and K. Helliwell, "Determination of rosmarinic acid and caffeic acid in aromatic herbs by HPLC," Food Chemistry, vol. 87, no. 2, pp. 307-311, 2004.

[31] P. H. Raven, R. F. Evert, and S. E. Eichhorn, Raven Biology of Plants, Worth, Freeman, New York, NY, USA, 6th edition, 1998.

[32] M. B. Hossain, D. K. Rai, N. P. Brunton, A. B. MartinDiana, and A. C. Barry-Ryan, "Characterization of phenolic composition in lamiaceae spices by LC-ESI-MS/MS," Journal of Agricultural and Food Chemistry, vol. 58, no. 19, pp. 10576$10581,2010$.

[33] N. Osakabe, A. Yasuda, M. Natsume, and T. Yoshikawa, "Rosmarinic acid inhibits epidermal inflammatory responses: anticarcinogenic effect of Perilla frutescens extract in the murine two-stage skin model," Carcinogenesis, vol. 25, no. 4, pp. 549-557, 2004.

[34] L. C. Luis and C. B. Johnson, "Seasonal variations of rosmarinic acid and carnosic acid in rosemary extracts. Analysis of their in vitro antiradical activity," Spanish Journal of Agricultural Research, vol. 3, no. 1, pp. 106-112, 2005.

[35] S. Dragland, H. Senoo, K. Wake, K. Holte, and R. Blomhoff, "Several culinary and medicinal herbs are important sources of dietary antioxidants," Journal of Nutrition, vol. 133, no. 5, pp. 1286-1290, 2003.

[36] B. L. Halvorsen, K. Holte, M. C. W. Myhrstad et al., "A systematic screening of total antioxidants in dietary plants," Journal of Nutrition, vol. 132, no. 3, pp. 461-471, 2002.

[37] G. I. Stafford, A. K. Jäger, and J. Van Staden, "Effect of storage on the chemical composition and biological activity of several popular South African medicinal plants," Journal of Ethnopharmacology, vol. 97, no. 1, pp. 107-115, 2005.

[38] M. Chohan, G. Forster-Wilkins, and E. I. Opara, "Determination of the antioxidant capacity of culinary herbs subjected to various cooking and storage processes using the ABTS*+ radical cation assay," Plant Foods for Human Nutrition, vol. 63, no. 2, pp. 47-52, 2008.

[39] J. H. Yoon and S. J. Baek, "Molecular targets of dietary polyphenols with anti-inflammatory properties," Yonsei Medical Journal, vol. 46, no. 5, pp. 585-596, 2005.

[40] C. H. Peng, J. D. Su, C. C. Chyau et al., "Supercritical fluid extracts of rosemary leaves exhibit potent anti-inflammation and anti-tumor effects," Bioscience, Biotechnology and Biochemistry, vol. 71, no. 9, pp. 2223-2232, 2007.

[41] L. A. Shelef, "Antimicrobial effects of spices," Journal of Food Safety, vol. 6, no. 1, pp. 29-44, 1984.

[42] M. H. Carlsen, R. Blomhoff, and L. F. Andersen, "Intakes of culinary herbs and spices from a food frequency questionnaire evaluated against 28-days estimated records," Nutrition Journal, vol. 10, no. 1, article 50, 2011. 


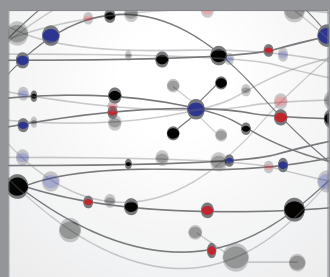

The Scientific World Journal
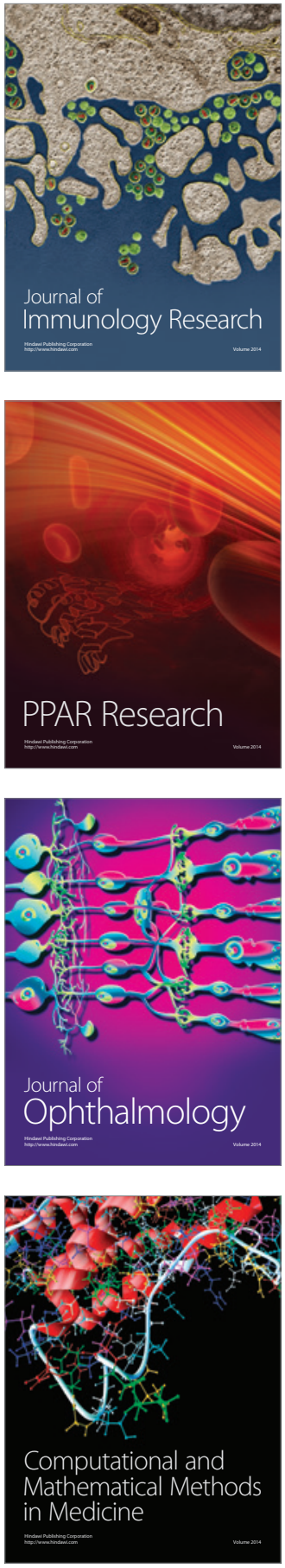



Gastroenterology

Research and Practice
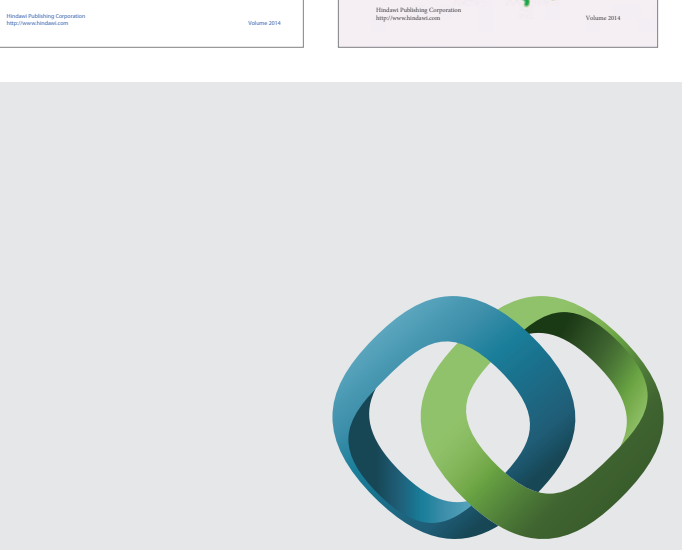

\section{Hindawi}

Submit your manuscripts at

http://www.hindawi.com


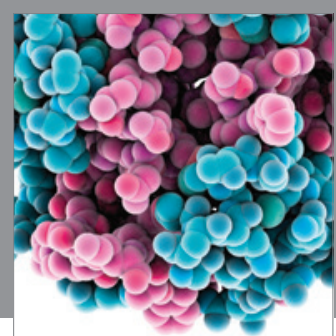

Journal of
Diabetes Research

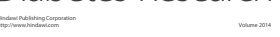

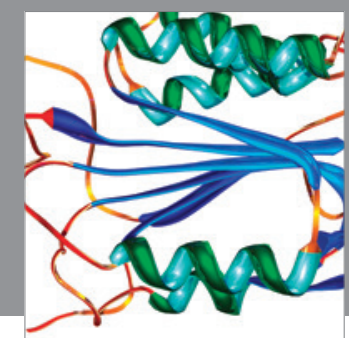

Disease Markers
